\title{
Improvement of some Quality Properties of Whole Meal Barley Flour Biscuits Using Resistant Starch and Whole Oat Flour
}

\author{
Ashgan Aly ${ }^{1}$ and Samaa Saleh ${ }^{* 2}$ \\ ${ }^{1}$ Bread and Pasta Research Department, Food Technology Research Institute, Agricultural Research Center, Egypt \\ ${ }^{2}$ Food Science Department, Saba Basha Agriculture Faculty, Alexandria University, Egypt
}

Received: 9/9/2021

\begin{abstract}
The effect of using resistant starch (RS) and whole oat flour (WOF) to improve the sensory and functional properties of whole meal barley biscuit (WMBF) was studied. The WMBF biscuit was made by substituting WOF and/or RS to formulate four formulas: $\mathrm{T} 1=90 \% \mathrm{WMBF}: 10 \% \mathrm{RS}, \mathrm{T} 2=90 \% \mathrm{WMBF}: 10 \% \mathrm{WOF}, \mathrm{T} 3=80 \% \mathrm{WMBF}$ : 10\% RS: $10 \%$ WOF and T4=70\% WMBF: $15 \%$ RS: 15\% WOF, whereas WMBF (cont.) used as control. The biscuits were evaluated for characterizes of making, chemical composition, texture, total phenolics content, its antioxidant activity and color attributes. Results indicated that using WOF was improved biscuit spread ratio and the most nutrients. As for sensory properties of resultant biscuits improved with supplementation with WOF and/or RS. Biscuit blend T4 had the highest appearance attribute (8.33). Texture of WMBF biscuit was become crispier with using WOF and /or RS, whereas the water activity of resultant biscuit was marginally affected. The total phenolics content of WMBF biscuit was the highest value for Cont. (725. $\$ 7 \mathrm{mg} \mathrm{GAE} / 100 \mathrm{~g}$ ) followed with biscuit blend T2 (621.42 mg GAE/100 g) as biscuit blends. The antioxidant activity of total phenolics was the highest value in biscuit blend T2 $(18.22 \%)$. The color of WMBF biscuit was improved to be redness and golden in biscuit blends. Thus, the goal of this study is achieved, which is production of WMBF biscuits with good nutritional value, sensory properties, color, taste, and over acceptability.
\end{abstract}

Keywords: Biscuit; nutritive value; oat flour; resistance starch; sensory properties; whole meal barley

\section{INTRODUCTION}

Grains are the primary source of carbohydrates and energy, for people all over the world. Moreover, most grains contain a lot of dietary fiber as well as various minerals, vitamins and phytochemicals (Poutanen et al., 2014). The consumption of whole grains is strongly associated with the reduction of the risk of acute and chronic illnesses, including type 2 diabetes, cardiovascular diseases and certain cancers, notably colorectal cancer (Aune et al., 2016).

Barley (Hordeum vulgare L.) is one of cereal crops, which is considered as a functional grain that due to contain phytochemicals such as tocotrienols, tocopherols and $\beta$-glucan, B-complex vitamins (Sharma and Gujral, 2010). Barley flour is plentiful in phenolic compounds, vitamin B complex, minerals, and dietary fiber (beta glucan), which assist to lower cholesterol by formation to bile acids and expelling them from the body, barley is one of the rich and inexpensive exporter of plant protein that can be utilized to improve the eating regimen of a huge number of individuals, particularly poor people and low salary workers in most countries (Vasan et al., 2017). The Food and Drug Administration advise consumption of $3 \mathrm{~g}$ of $\beta$ - glucan soluble fiber from barley or oat products every day to get bringing down of low serum cholesterol (Verma and Banerjee, 2010).

Oatmeal (Avena sativa L.) is a nutritious ingredient which is balanced for human health. Oat consumption is believed to have a number of health benefits, including hypocholesterolemia and anticancer properties. Oatmeal has been deemed suitable in the diet of patients suffering from celiac disease. Because of their high degree of nutrition, oatmeal such as breads, cookies, functional drinks, cereal flakes and infant foods are becoming more important (Rasane et al., 2015).

Barley and oats are now increasingly referred to as functional food ingredients because it is regarded as a rich source of B-glucans; a non-starch polysaccharide available in the cell walls of the aleurone in bran (Soares et al., 2007). Barley and oats beta-glucan are effective in flattening post-prandial blood sugar levels and reducing cardiovascular risk factors compared to other sources of soluble fiber (Baik and Ullrich, 2008).

Resistance starch (RS) is commonly used as the dietary ber in baked goods, which is resistant to digestion in the stomach, small intestine and colon, having some nutritional bene ts such as positive effects on the digestive system, blood cholesterol levels and glycemic response (Wang et al., 2016). Additionally, Englyst et al. (1992) classified resistant starch into three main types: RS-1 is the most physically inaccessible, it is partially grains, seeds and legumes. RS-2 granules remain intact and resistant to enzyme action. Examples include raw potatoes, bananas and high-starch maize starches. RS-3 is retrograded starch that is present in bread, cooked and cooled potatoes, and ready-to-eat breakfast cereal (Baghurst et al., 1996). Besides these three major types of chemically modified resistant starch, starch has been identified as RS-4 (Lineback, 1997).

Biscuits are the most well-known bakery items consumed almost by all sections of the general public in Egypt, some of the causes for such wide prominence are reduce cost in comparison with other manufactory foods, great nutritional quality and accessibility in various structures, various taste and longer shelf life, bakery products are utilized for incorporation of various nutritionally rich ingredients (Sudha et al., 2007). The biscuits quality relies on amount and 
quality of contents (especially the flour), it was discovered that blending two or more distinct materials help to solve the insufficiency problem of grains as Increases nutritional value by utilized different seed as high nutritive source (Shalini and Sudesh, 2005). The improving nutritional value of a commercially applicable biscuit ought to appeal to children and grownup, increase ratio in protein, vitamins, and fibers in biscuit, the sensory and textural quality of biscuit are taken into consideration to improve the quality of biscuit (Miranda et al., 2010).

A number of studies have shown that the hardness of product was higher with the increasing level replacement of whole barley flour in bakery products (Newman et al., 1998). Moreover, Gupta et al. (2011) studied wheat biscuits fortified with barley flour and found that their color changed with barley flour incorporation from pale cream to golden brown. They attributed the darker of color wheat barley biscuit due to rich barley flour with pigments. Generally, the flour color is depended on its botanical source and its content of pigments. Additionally, barley flour is good source of phenolics (Sharma et al., 2012). Cereal phytochemicals such as phenolics, they have an impact on reducing the quality of the bakery products in terms of color, texture and taste (Lesschaeve and Noble, 2005).

The aim of the present study was to substitute the whole meal barley flour in biscuit by resistance starch (RS) and whole meal oat flour (WOF) in order to raise nutritional value and to improve sensory attributes of biscuit subsequently to get a high-quality product.

MATERIALS AND METHODS

Table (1): Formulas (g) of WMBF biscuit supplemented with WOF and /or RS

\begin{tabular}{lccccc}
\hline \multirow{2}{*}{ Ingredients } & \multicolumn{2}{c}{ Blends of WMBF biscuit } & T2 & T3 & T4 \\
\cline { 2 - 6 } WMBF $^{*}$ & Cont. $^{* *}$ & T1 & 90 & 80 & 70 \\
WOF & 100 & 90 & 10 & 10 & 15 \\
RS & - & - & - & 10 & 15 \\
Sugar & - & 10 & 36 & 36 & 36 \\
Fat(butter) & 36 & 36 & 33 & 33 & 33 \\
Baking powder & 33 & 33 & 3 & 3 & 3 \\
Salt & 3 & 3 & 1 & 1 & 1 \\
Vanillin & 1 & 1 & 0.25 & 0.25 & 18 \\
Water & 0.25 & 0.25 & 18 & 0.25 \\
\hline
\end{tabular}

"WMBF $=$ Whole meal barley flour, $\mathrm{WOF}=$ Whole oat flour and RS= Resistant starch

${ }^{* *}$ Cont. $=100 \%$ WMBF used as control, whereas biscuit blends were $\mathrm{T} 1=90 \% \mathrm{WMBF}: 10 \% \mathrm{RS}, \mathrm{T} 2=90 \% \mathrm{WMBF}: 10 \% \mathrm{WOF}, \mathrm{T} 3=$ 80\% WMBF: $10 \%$ RS: $10 \%$ WO F and T4=70\% WMBF: $15 \%$ RS: $15 \%$ WOF

\section{Sensory evaluation:}

The samples of biscuit were evaluated by ten experts trained in Bread and Pastry, Bread and Pasta Research Dept., Food Technology Research Institute, Agric. Res. Center, Giza. WMBF biscuit (cont.1) was used as control to judge with other samples. The biscuits sensorial tested for appearance, taste, odor, color, mouth feel and general acceptance degree were evaluated through the nine-point hedonic (from like

\section{Materials:}

The grains of naked barley (Hordeum vulgare L.) variety Giza131 was obtained from the Field Crops Research Institute, Giza, Egypt. The barley grains were milled and equipped with a $1.0 \mathrm{~mm}$ sieve to obtain whole meal barley flour (WMBF). The flour was stored in an airtight container in the refrigerator at $4^{\circ} \mathrm{C}$ until use.

-Resistant starch (RS) (thermal treated) was obtained from Egyptian starch and glucose Co. Cairo, Egypt.

- Whole oat flour (WOF) and other biscuit ingredients were obtained from the local market of Cairo, Egypt.

- All chemicals utilized in the study were of analytical type.

\section{Methods: \\ Biscuit Processing}

Biscuit blends were prepared by following standard recipe and baking conditions using the method described by Laguna et al. (2011), which mentioned in Table (1). The different blends of biscuit were prepared by partial replacement of WMBF to formulate four formulas: $\mathrm{T} 1=90 \% \mathrm{WMBF}: 10 \% \mathrm{RS}, \mathrm{T} 2=90 \%$ WMBF: $10 \%$ WOF, T3= 80\% WMBF: $10 \%$ RS: $10 \%$ WOF and T4=70\% WMBF: $15 \%$ RS: $15 \%$ WOF, whereas WMBF (Cont.) used as control.

\section{Physical characteristics of biscuits}

After cooling biscuit samples, physical properties of biscuit samples such as weight $(\mathrm{g})$, diameter $(\mathrm{cm})$, volume $\left(\mathrm{cm}^{3}\right)$, bulk density $\left(\mathrm{g} / \mathrm{cm}^{3}\right)$, thickness $(\mathrm{cm})$, specific volume $\left(\mathrm{cm}^{3} / \mathrm{g}\right)$ and spread ratio (diameter/thickness) were measured as described by Drakos et al. (2019). 


\section{Determination of minerals:}

Mineral content $(\mathrm{Zn}, \mathrm{K}, \mathrm{Mg}, \mathrm{Mn}, \mathrm{Ca}$, and $\mathrm{Cu})$ of the resultant biscuit samples was determined by using SHIMADZU atomic absorption spectroscopy AA6800, Japan as described by AOAC (2000).

\section{Texture analysis:}

Texture analyzer (Brookfield CT3 No. M08-372C0113, USA) was utilized to measure the texture profile of the biscuit samples at zero time and end of storage time (3 months) in terms of hardness $(\mathrm{N})$, fracturability $(\mathrm{mm})$ of samples following the method outlined by Meullenet et al. (1998).

\section{Evaluation of water activity $\left(a_{w}\right)$ :}

The water activity of the resultant biscuit samples was measured with a Rotronic (model Hygrolab3, Switzerland). The ground sample of biscuit at zero time and end of storage time ( 3 months) was filled into the plastic cups approaching from above then the Hygroplam probe was inserted in these cups. After about three to four minutes the display was exhibited the water activity, and temperature. The measurements were replicated three times (Piga et al., 2005).

\section{Determination of free, bound and total phenolics contents}

Free and bound phenolics content of both WMBF and WOF flour as raw material and the resultant biscuit samples were determined for determining total phenolics content according to the Foline Ciocalteu spectrophotometric method as described by McDonald et al. (2001). The results were expressed as equivalents Gallic acid mg( GAE) /100 g dry matter in the sample. Antioxidant activity (DPPH radical scavenging activity):

Radical scavenging activity (DPPH) was estimated of WMBF and WOF flour as raw material and the resultant biscuit samples according to the method mentioned by McDonald et al. (2001).

Color measurements of the resultant biscuit samples:

The crust color of biscuits was determined depending on the method substantive by Laguna et al. (2011). The $L^{*}, a^{*}$ and $b^{*}$ values for color were evaluated using a Konica Minolta CR-410 Chroma meter (Konica Minolta, Sensing, INC., Japan). The measurements were replicated three times.

\section{Statistical analysis}

The results were analyzed using CoStat, version 3.03 for PC, as explained by Ott (1988). The tests used were ANOVA test and descriptive statistics tests. A treatment effect was postulated to be statistically significant at $P \leq 0.05$.

\section{RESULTS AND DISCUSSION}

\section{Physical properties of the resultant WMBF biscuits}

The effect of replacement of the WMBF by WOF and/or RS on the baking quality of the resultant biscuit is presented in the Table (2). The thickness and volume of the resultant biscuit have been meaningfully increased in the blend T3, which is consist of $10 \%$ WOF and $10 \% \mathrm{RS}$ as replacement ratio, which registered $3 \mathrm{~cm}$ and $53.67 \mathrm{~cm}^{3}$, respectively. This effect can be attributed to the high fiber content of WOF and the RS, Laguna et al. (2011) and Hoda et al. (2018) reported these findings. Moreover, the diameter and spread ratio have been considerably increased compared to the control sample of WMBF (Cont.) affected by the replacement of WOF and RS. The highest diameter value was in the T2 and T3 blends, which recorded $4.53 \mathrm{~cm}$. As well, the result has been accepted with Hoda et al. (2018) who pointed to that adding oatmeal to barley flour resulted in an increase in the volume of biscuits. In addition, Sharma and Gujral (2014) observed that the spread factor of the cookies decreased because of the higher ratio of barley flour. Our findings support those of Laguna et al. (2011) which stated that, in the resistant starch biscuits (RS) the greater the quantity of RS, the least is the width and length of the cookie and the thickness of the biscuit in relation to the check wheat biscuit. Pareyt et al. (2008) stated that soft wheat ( $8 \%$ to $11 \%$ protein) has more use in cakes, cookies, crackers and pretzels, which the spread ratio decreased linear with increase gluten content. The results are in agreement with the results reported by Makpoul and Ibrahem (2015). Such differences in the physical properties could be attributed to properties in the raw materials.

Table (2): Physical properties of the resultant WMBF biscuits

\begin{tabular}{cccccccc}
\hline Sample & $\begin{array}{c}\text { Diameter } \\
(\mathbf{c m})\end{array}$ & $\begin{array}{c}\text { Thickness } \\
(\mathbf{c m})\end{array}$ & $\begin{array}{c}{ }^{* * *} \text { Spread } \\
\text { ratio }\end{array}$ & $\begin{array}{c}\text { weight } \\
(\mathbf{g})\end{array}$ & $\begin{array}{c}\text { Volume } \\
\left(\mathbf{c m}^{\mathbf{3}}\right)\end{array}$ & $\begin{array}{c}\text { Bulk density } \\
\left(\mathbf{g} / \mathbf{c m}^{3}\right)\end{array}$ & $\begin{array}{c}\text { Specific volume } \\
\left(\mathbf{c m}^{3} / \mathbf{g}\right)\end{array}$ \\
\hline Cont. $^{*}$ & $4.33^{\mathrm{b}}$ & $2.73^{\mathrm{b}}$ & $1.58^{\mathrm{ab}}$ & $31.96^{\mathrm{a}}$ & $41.67^{\mathrm{c}}$ & $0.76^{\mathrm{a}}$ & $1.30^{\mathrm{b}}$ \\
T1 & $4.37^{\mathrm{b}}$ & $2.90^{\mathrm{a}}$ & $1.51^{\mathrm{b}}$ & $29.06^{\mathrm{b}}$ & $50.00^{\mathrm{b}}$ & $0.58^{\mathrm{b}}$ & $1.72^{\mathrm{a}}$ \\
T2 & $4.53^{\mathrm{a}}$ & $2.77^{\mathrm{b}}$ & $1.64^{\mathrm{a}}$ & $28.90^{\mathrm{b}}$ & $50.00^{\mathrm{b}}$ & $0.58^{\mathrm{b}}$ & $1.72^{\mathrm{a}}$ \\
T3 & $4.53^{\mathrm{a}}$ & $3.00^{\mathrm{a}}$ & $1.51^{\mathrm{b}}$ & $31.93^{\mathrm{a}}$ & $53.67^{\mathrm{a}}$ & $0.59^{\mathrm{b}}$ & $1.68^{\mathrm{a}}$ \\
T4 & $4.37^{\mathrm{b}}$ & $2.60^{\mathrm{c}}$ & $1.68^{\mathrm{a}}$ & $27.56^{\mathrm{c}}$ & $48.00^{\mathrm{b}}$ & $0.57^{\mathrm{b}}$ & $1.74^{\mathrm{a}}$ \\
\hline
\end{tabular}

Cont. $=100 \%$ WMBF used as biscuit sample control, whereas biscuit blends were T1 $=90 \%$ WMBF: $10 \%$ RS, T2=90\%WMBF:

$10 \%$ WOF, T3 $=80 \%$ WMBF: $10 \%$ RS: $10 \%$ WO F and T4=70\% WMBF: $15 \%$ RS: $15 \%$ WOF.

${ }^{* *}$ Spread ratio $=$ diameter/thickness ${ }^{* * *}$ Means in the same column with different letters are significantly different $(p \leq 0.05)$ 


\section{Sensory evaluation of the resultant WMBF biscuits}

Sensory assessment is a scientific discipline utilized for evaluate, analyze and interpret responses that are characteristics of the products and other materials are seen by the senses of sight, smell, taste, feel and hearing (Stone and Sidel, 2004). The samples of biscuit prepared from WMBF with WOF and/or RS were assessed for their quality attributes, including appearance, color, odor, taste, mouth feel and general acceptance. The data obtained were analyzed statistically and the values are given in Table (3). The WMBF biscuit had the lowest values for global sensory evaluation. These values have been significantly improved by the inclusion of WOF and RS in the manufacture of the biscuit. Appearance attributes had the highest value in the blend T4 $(70 \% \mathrm{WMBF}, 15 \%$ RS and $15 \%$ WOF), which was 8.33. On the other hand, the favorite color was in the biscuit blend $\mathrm{T} 2$
(90\% WMBF and 10\% WOF), whereas other blends had highest in color values compared with biscuit Cont. $(100 \% \mathrm{WMBF})$. This can be attributed to the use of $\mathrm{RS}$, which did not interfere in the Millard reaction, which responsible of the brown color in the biscuit. Baixauli et al. (2008) found that the using of the RS in biscuit formulations was diluted the pigmented elements of the formulation. In addition, odor, taste and mouth feel recorded the highest values in biscuit blend T3 (80\% WMBF: 10\% RS: 10\% WOF) were 8.5, 8.5 and 8.67 , respectively. The highest level (8.67) of general acceptance recorded in both biscuit blends $\mathrm{T} 2$ and T3, which prepared from 90\% WMBF: $10 \% \mathrm{WOF}$ and $80 \%$ WMBF: $10 \%$ RS: $10 \%$ WOF, respectively. Laguna et al. (2011) indicated that acceptance ratings for wheat control and $20 \%$ RS biscuit is not significantly different from sensorial attributes.

Table (3): Sensory evaluation of biscuits produced WMBF supplemented with different levels of RS and /or WOF

\begin{tabular}{|c|c|c|c|c|c|c|}
\hline Sample & Appearance & Color & Odor & Taste & Mouth feel & $\begin{array}{c}\text { General } \\
\text { acceptance }\end{array}$ \\
\hline Cont.* & $6.17^{\mathrm{c}} \pm 0.40$ & $5.67^{\mathrm{b}} \pm 0.82$ & $7.17^{\mathrm{c} \pm} 0.41$ & $7.17^{b} \pm 0.75$ & $6.83^{c} \pm 0.75$ & $6.67^{c} \pm 0.82$ \\
\hline $\mathbf{T 1}$ & $7.17^{\mathrm{b} \pm} 0.75$ & $7.67^{\mathrm{a}} \pm 0.52$ & $7.83^{\mathrm{b} \pm} 0.41$ & $7.50^{\mathrm{ab}} \pm 0.55$ & $7.50^{\mathrm{b}} \pm 0.55$ & $6.83^{c} \pm 0.41$ \\
\hline $\mathbf{T} 2$ & $7.50^{\mathrm{b}} \pm 0.55$ & $8.50^{\mathrm{a}} \pm 0.55$ & $7.67^{b c} \pm 0.52$ & $7.83^{\mathrm{a}} \pm 0.41$ & $8.33^{\mathrm{a}} \pm 0.52$ & $8.67^{\mathrm{a}} \pm 0.52$ \\
\hline T3 & $8.17^{\mathrm{a}} \pm 0.40$ & $8.33^{\mathrm{a}} \pm 0.82$ & $8.50^{\mathrm{a} \pm} 0.55$ & $8.50^{\mathrm{a} \pm} 0.55$ & $8.67^{\mathrm{a}} \pm 0.52$ & $8.67^{\mathrm{a}} \pm 0.52$ \\
\hline T4 & $8.33^{\mathrm{a} \pm} 0.52$ & $8.17^{\mathrm{a}} \pm 0.75$ & $8.00^{\mathrm{ab}} \pm 0.63$ & $8.17^{\mathrm{a}} \pm 0.41$ & $7.50^{\mathrm{b}} \pm 1.05$ & $7.83^{\mathrm{b}} \pm 0.41$ \\
\hline
\end{tabular}

"Cont. $=100 \%$ WMBF used as control, whereas biscuit blends were T1 $=90 \% \mathrm{WMBF}: 10 \% \mathrm{RS}, \mathrm{T} 2=90 \% \mathrm{WMBF}: 10 \% \mathrm{WOF}, \mathrm{T} 3=$ $80 \%$ WMBF: $10 \%$ RS: $10 \%$ WOF and T4=70\% WMBF: $15 \%$ RS: $15 \%$ WOF.

${ }^{* *}$ Means in the same column with different letters are significantly different $(p \leq 0.05)$. Each mean value is followed by $\pm \mathrm{SE}$ (standard error) for triplicate of samples.

\section{Chemical composition of biscuits made from WMBF with partial replacement by WOF and / or RS}

The chemical composition results for resultant biscuits are presented in Table (4). Protein content of biscuit blends T4 (70\% WMBF: 15\% RS: 15\% WOF) and Cont. (100\% WMBF) was $2.08 \%$ and $2.63 \%$ respectively. The ash content was highest in their Cont. $(100 \%$ WMBF) sample, whereas the lowest value $(1.95 \%)$ was observed in the biscuit blend $\mathrm{T} 3(80 \%$ WMBF: $10 \%$ RS: $10 \%$ WOF). Furthermore, the highest value of carbohydrates and moisture content recorded in biscuit blend T3 (80\% WMBF: $10 \% \mathrm{RS}$ : $10 \%$ WOF) $(77.24 \%$ and $4.55 \%)$, respectively. Oatmeal is considered a naturally occurring source of protein, minerals, high in dietary fiber, which have antioxidant activity with a low and thermally stable glycemic index (GI) during food processing (Rasane et al., 2015). Therefore, oatmeal may be promoted as a functional and safe ingredient within the food industry. The results reported comply with Rasane et al. (2015) and Hoda et al. (2018) they stated that adding oatmeal to whole wheat flour caused a significant increase in fiber and ash, and low protein and carbohydrate compared with whole wheat flour biscuit products.

\section{Mineral content of the resultant WMBF biscuits}

Minerals must come from food because the body is not able to synthesize them. According to estimates, more than $60 \%$ of the global population suffers from a lack of iron, over $30 \%$ is a deficiency in $\mathrm{Zn}$ and around $15 \%$ is a deficiency in Se. Deficiencies in $\mathrm{Ca}, \mathrm{Mg}$ and $\mathrm{Cu}$ are scarce, but can occur in certain population groups. Food malnutrition problems are usually resolved by supplementation, food fortification or food diversification (White and Broadley, 2007).

Data presented in Table (5) showed the mineral content of the resultant biscuits. The obtained data showed that the barley biscuit $(100 \% \mathrm{WMBF})$ was the highest in the most elements such as $\mathrm{K}, \mathrm{Ca}$, and $\mathrm{Cu}$ were $2492.84,1323.57$, and $6.31 \mathrm{mg} / \mathrm{kg}$ respectively comparing with the other resultant biscuit samples. The best blend of resultant biscuit in the mineral content was T2 (90\%WMBF: $10 \%$ WOF), which was the highest in the most elements and it was superior than Cont. (100\% WMBF) in $\mathrm{Zn}, \mathrm{Mg}$, and Mn were 13.84, 1146.90 , and $15.99 \mathrm{mg} / \mathrm{kg}$ respectively. 
Table (4): The proximate analysis of the resultant WMBF Biscuits

\begin{tabular}{ccccccc}
\hline Samples & $\begin{array}{c}\text { Crude Protein } \\
(\text { *5.75) }\end{array}$ & Ash & Crude Fat & Crude Fiber & Total carbohydrates & Moisture \\
\hline Cont. & $2.63^{\mathrm{a}}$ & $2.88^{\mathrm{a}}$ & $16.06^{\mathrm{b}}$ & $2.69^{\mathrm{a}}$ & $75.74^{\mathrm{b}}$ & $3.92^{\mathrm{c}}$ \\
T1 & $2.28^{\mathrm{c}}$ & $2.62^{\mathrm{b}}$ & $15.86^{\mathrm{b}}$ & $2.41^{\mathrm{b}}$ & $76.84^{\mathrm{a}}$ & $4.36^{\mathrm{b}}$ \\
T2 & $2.46^{\mathrm{b}}$ & $2.60^{\mathrm{b}}$ & $17.04^{\mathrm{a}}$ & $2.59^{\mathrm{a}}$ & $75.31^{\mathrm{b}}$ & $3.30^{\mathrm{d}}$ \\
T3 & $2.17^{\mathrm{c}}$ & $1.95^{\mathrm{c}}$ & $17.01^{\mathrm{a}}$ & $2.28^{\mathrm{c}}$ & $77.24^{\mathrm{a}}$ & $4.55^{\mathrm{a}}$ \\
T4 & $2.08^{\mathrm{cd}}$ & $2.57^{\mathrm{b}}$ & $17.42^{\mathrm{a}}$ & $2.23^{\mathrm{c}}$ & $75.70^{\mathrm{b}}$ & $3.33^{\mathrm{d}}$ \\
\hline
\end{tabular}

Cont. $=100 \% \mathrm{WMBF}$ used as control, whereas biscuit blends were $\mathrm{T} 1=90 \% \mathrm{WMBF}: 10 \% \mathrm{RS}, \mathrm{T} 2=90 \% \mathrm{WMBF}: 10 \% \mathrm{WOF}, \mathrm{T} 3=$ 80\% WMBF: $10 \%$ RS: $10 \%$ WOF and T4=70\% WMBF: $15 \%$ RS: $15 \%$ WOF.

${ }^{* *}$ Means in the same column with different letters are significantly different $(p \leq 0.05)$

Table (5): Minerals contents (mg/kg dry sample) of the resultant WMBF biscuits

\begin{tabular}{cccccccc}
\hline Sample & Zn & K & Mg & Mn & Ca & Cu \\
\hline Cont. & 13.64 & 2492.84 & 1130.92 & 9.77 & 1323.57 & 6.31 \\
T1 & 13.38 & 2442.33 & 817.74 & 8.34 & 1297.97 & 4.49 \\
T2 & 13.84 & 2485.57 & 1146.90 & 15.99 & 1313.73 & 6.21 \\
T3 & 13.29 & 2470.71 & 1101.20 & 9.25 & 1320.03 & 6.12 \\
T4 & 12.28 & 1987.74 & 995.61 & 8.03 & 917.19 & 4.38 \\
\hline
\end{tabular}

Cont. $=100 \%$ WMBF used as control, whereas biscuit blends were T1 $=90 \%$ WMBF: $10 \%$ RS, T2=90\%WMBF: $10 \%$ WOF, T3= 80\% WMBF: $10 \%$ RS:10\% WO F and T4=70\% WMBF: $15 \%$ RS: $15 \%$ WOF.

Hendek et al. (2020) concluded that most of the minerals $(>90 \%)$ are found in the outer layers of the kernels, particularly in the bran, the aleurone layer and the germ.

Consequently, whole grain products are increasingly expected to be introduced into the human diet for the benefit of the mineral content of cereals. Rasance et al. (2015) mentioned that oats contained trace elements like folate, zinc, iron, selenium, copper, manganese, carotenoids, betaine, choline, amino acids containing sulfur and phytic acid.

Texture and water activity of the resultant WMBF biscuit during storage time ( 3 months) at ambient temperature

The main objective of this research was to improve the texture property of WMBF biscuits by using WOF and/or RS. Presented data in Table (6) showed hardness force as an indicator to the texture of biscuit at zero time and end of storage time ( 3 months) at ambient temperature $\left(25 \pm 3^{\circ} \mathrm{C}\right)$. It could be noticed that the hardness force at zero time of WMBF (Cont.) biscuit sample had the highest value $(12.48 \mathrm{~N})$, whereas biscuit blend T3 (80\% WMBF: 10\% RS: $10 \%$ WOF) had the lowest value $(7.30 \mathrm{~N})$. Moreover, the hardness force of all biscuit samples decreased with the end of storage time. This may be due to WMBF products are characterized with hardness, which may be due to a particular protein. On the other hand, the biscuit formula T3 (80\% WMBF: $10 \% \mathrm{RS}: 10 \% \mathrm{WOF}$ ) is characterized with crispness that due to starch granules or RS. Our results are consistent with Sharma and Gujral (2014) reported that the snap force of barley flour cookies was the highest, which decreased with increasing wheat flour levels in cookies. Similarly, Laguna et al. (2011) reported that the increasing supplementation levels of RS the breaking strength and crumbliness increased in the final product. Additionally, Ovando-Martinez et al. (2013) declared that oatmeal contained large quantities of RS and different starch fractions. Total starch of oats consisted of approximately $25 \%$ resistant starch, $22 \%$ slowly digested starch and $7 \%$ rapidly digestible starch.

Water activity results of the final product at zero time and end of storage time ( 3 months) at room temperature $\left(25 \pm 3^{\circ} \mathrm{C}\right)$ are displayed in Table (6). It could be observed that water activity of biscuit samples at zero time was marginally affected with used the WOF and/or RS. WMBF biscuit (Cont.) had the highest value $(0.43)$ which slightly decreased or not effected with used WOF andor RS. Additionally, with elongate storage period the water activity slightly increased in all biscuit samples. This could be attributed to the high fiber content in WMBF and WOF, which had an efficiency of holding water (Lebesi and Tzia, 2011). The obtained results are consistent with those of Sharma and Gujral (2014) they found that the water activity of barley flour cookies was the highest which reduced with increasing wheat flour levels and they attributed that to barley flour is considered a rich source of fiber. 
Table (6): Texture profile and water activity $\left(\mathrm{a}_{\mathrm{w}}\right)$ parameters of the resultant WMBF biscuit with WOF and /or R.S at zero time and end of storage time ( 3 months) at room temperature $(25 \pm 3 \quad$ C)

\begin{tabular}{|c|c|c|c|c|c|}
\hline Samples & Period storage & $\begin{array}{c}\text { Hardness(N) } \\
\text { Force(g) }\end{array}$ & $\begin{array}{l}\text { Fracturability } \\
\text { Distance(mm) }\end{array}$ & $\mathbf{a}_{\mathrm{w}}$ & $\mathbf{C}^{* * * *}$ \\
\hline \multirow{2}{*}{ Cont. * } & $\mathrm{Z} \mathrm{T}^{* *}$ & 12.48 & 1.00 & $0.43^{\mathrm{a}^{* * *}}$ & $23.50^{\mathrm{a}}$ \\
\hline & E. T & 11.97 & 4.00 & $0.45^{\mathrm{c}}$ & $24.50^{\mathrm{c}}$ \\
\hline \multirow{2}{*}{ T1 } & Z. T & 10.10 & 1.00 & $0.43^{\mathrm{a}}$ & $23.40^{\mathrm{a}}$ \\
\hline & E. T & 6.14 & 1.00 & $0.44^{\mathrm{d}}$ & $24.62^{b}$ \\
\hline \multirow{2}{*}{$\mathbf{T 2}$} & Z. T & 9.40 & 1.00 & $0.40^{\mathrm{b}}$ & $23.15^{\mathrm{a}}$ \\
\hline & E. T & 5.59 & 2.00 & $0.45^{\mathrm{c}}$ & $24.73^{\mathrm{a}}$ \\
\hline \multirow[b]{2}{*}{ T3 } & Z. T & 7.30 & 1.00 & $0.43^{\mathrm{a}}$ & $23.42^{\mathrm{a}}$ \\
\hline & E. $T$ & 5.89 & 2.00 & $0.47^{\mathrm{b}}$ & $24.71^{\mathrm{a}}$ \\
\hline \multirow{2}{*}{ T4 } & Z. T & 8.21 & 1.00 & $0.41^{\mathrm{b}}$ & $23.43^{\mathrm{a}}$ \\
\hline & E. $T$ & 5.84 & 1.00 & $0.48^{\mathrm{a}}$ & $24.79^{\mathrm{a}}$ \\
\hline
\end{tabular}

Cont. $=100 \%$ WMBF used as control, whereas biscuit blends were T1=90\% WMBF:10\% RS, T2=90\%WMBF: $10 \%$ WOF, T3= 80\% WMBF: $10 \% \mathrm{RS}: 10 \% \mathrm{WO} \mathrm{F}$ and T4=70\% WMBF: $15 \% \mathrm{RS}: 15 \% \mathrm{WOF}$.

${ }^{* *} \mathrm{Z} . \mathrm{T}=$ zero time of storage and $\mathrm{E} . \mathrm{T}=$ end time of storage $(3 \mathrm{months})$ at room temperature

${ }^{* * *}$ Means in the same column with different letters are significantly different $(\mathrm{p} \leq 0.05)$.

${ }^{* * * *} \mathrm{C}=$ temperature degree during measuring $\mathrm{a}_{\mathrm{w}}$

Free, bound and total phenolics content and antioxidant activity of the resultant WMBF biscuits

Barley is considered as functional cereal because it has high content of phenolic compounds, mostly referred to as antioxidants. The intake of food rich in phenolics could be lowered the possible risks by consuming oxidation products and free radicals (Sharma and Gujral, 2014). The data of functional components content such as free phenolics presenting in raw flour and biscuit samples are shown in Table (7). It could be noted that free phenolics content was higher in WMBF (448.41 mg GAE/100 g) than WOF as raw materials, which greatly decreased by baking process. The highest content of free phenolics content (350.46 mg GAE/ $100 \mathrm{~g}$ ) was recorded in biscuit blend T3 (80\% WMBF: $10 \%$ RS: $10 \%$ WOF). The reduction of free phenolics content may be related to degradation the free phenolics compounds by thermal process and its content in the WOF and RS was lower than WMBF. The given data are similarly with those of Holtekjølen et al. (2008) they revealed that the content of free phenolics decreased during the thermal process of wheat flour bread fortified with whole barley flour.

The bound phenolics content of raw flour and biscuit samples ranged from $70.88 \mathrm{mg}$ GAE/100 g: $445.16 \mathrm{mg} \mathrm{GAE} / 100 \mathrm{~g}$ are given in Table (7). It was noted that the bound phenolics content of WOF was the higher than $\mathrm{WMBF}$ as raw materials and by baking process the bound phenolics content increased. From the biscuit blends, the blend T2 (90\%WMBF: $10 \%$ WOF) had the highest (445.16 mg GAE/100 g) of bound phenolics content. The increasing of bound phenolics content after baking may be attributed to that during the baking process the dark color pigments (brown color) forms as resulting Maillard reaction, which have been proved to have antioxidant activity accordance (Vitali et al., 2009).

The total phenolics content and antioxidant activity of raw flour and biscuit samples are provided in Table (7). It could be observed that total phenolics content and its antioxidant activity increased by baking process slightly. This increasing could be attributed to increase the bound phenolics content. The obtained results were in consistence with those given by Holtekjølen et al. (2008) who illustrated that incorporation $40 \%$ barley flour with wheat flour and after the thermal process increased the total phenolics content and its antioxidant activity in produced bread compared with $100 \%$ wheat bread. In this respect, Bondia-Pons et al. (2009) mentioned that one of the health influences of cereal crops is attributed to numerous polyphenols that they have which can have anti-inflammatory, antioxidative and anti-cancerogenic properties. Thereby, it is suggested that grain phytochemicals can be a prophylactic agent against degenerative diseases. 
Table (7): The content of free phenolics (TPC-F), bound phenolic (TPC-B), total phenolics (TPC-T) and antioxidant activity of total phenolics (DPPH-TPC) for WMBF, WOF and the resultant WMBF biscuit blends with WOF and /or RS

\begin{tabular}{|c|c|c|c|c|}
\hline Sample & $\begin{array}{c}\text { TPC-F } \\
(\mathrm{mg} \mathrm{GAE} / 100 \mathrm{~g})\end{array}$ & $\begin{array}{c}\text { TPC-B } \\
(\mathrm{mg} \mathrm{GAE} / 100 \mathrm{~g})\end{array}$ & $\begin{array}{c}\text { TPC-T } \\
(\mathrm{mg} \mathrm{GAE} / 100 \mathrm{~g})\end{array}$ & DPPH -TPC (\%) \\
\hline $\begin{array}{c}\text { WMBF } \\
\text { WOF }\end{array}$ & $\begin{array}{l}448.41^{\mathrm{a}} \pm 0.48 \\
412.59^{\mathrm{b}} \pm 0.42\end{array}$ & $\begin{array}{c}70.88^{\mathrm{f}} \pm 0.44 \\
103.93^{\mathrm{e}} \pm 0.88\end{array}$ & $\begin{array}{c}519.29^{\mathrm{f**}} \pm 0.92 \\
516.5^{\mathrm{r}} \pm 1.30\end{array}$ & $\begin{array}{l}17.48^{\mathrm{ab}} \pm 0.82 \\
17.60^{\mathrm{ab}} \pm 0.53\end{array}$ \\
\hline Cont & $294.75^{\mathrm{d}} \pm 0.85$ & $430.71^{\mathrm{b}} \pm 0.62$ & $725 . \varepsilon 7^{\mathrm{a}} \pm 0.32$ & $17.84^{\mathrm{a}} \pm 0.15$ \\
\hline $\mathbf{T 1}$ & $264.76^{\mathrm{f}} \pm 0.25$ & $388.28^{\mathrm{c}} \pm 0.32$ & $653.04^{c} \pm 0.57$ & $16.30^{c} \pm 0.08$ \\
\hline $\mathbf{T} 2$ & $276.40^{\mathrm{e}} \pm 0.41$ & $445.16^{\mathrm{a}} \pm 0.65$ & $7 r 1.5^{r^{\mathrm{b}}} \pm 1.05$ & $18.22^{\mathrm{a}} \pm 0.29$ \\
\hline T3 & $350.46^{\mathrm{c}} \pm 0.54$ & $270.96^{\mathrm{d}} \pm 0.82$ & $6 ץ 1.42^{\mathrm{d}} \pm 0.59$ & $17.29^{\mathrm{ab}} \pm 0.14$ \\
\hline T4 & $223.48^{\mathrm{g}} \pm 0.53$ & $384.29^{c} \pm 0.72$ & $607.7 v^{\mathrm{e}} \pm 1.24$ & $16.01^{\mathrm{c}} \pm 0.20$ \\
\hline
\end{tabular}

WMBF $=$ Whole meal barley flour, WOF $=$ Whole Oat flour as raw materials, whereas Cont. = biscuits with $100 \%$ WMBF used as biscuit samples control and biscuit blends were T1 $=90 \% \mathrm{WMBF}: 10 \% \mathrm{RS}, \mathrm{T} 2=90 \% \mathrm{WMBF}: 10 \% \mathrm{WOF}, \mathrm{T} 3=80 \% \mathrm{WMBF}: 10 \%$ RS: $10 \%$ WO F and T4=70\% WMBF: $15 \%$ RS: $15 \%$ WOF.

${ }^{* *}$ Means in the same column with different letters are significantly different $(p \leq 0.05)$. TPC are expressed as gallic acid equivalents (GAE) (mg GAE/100g), while the antioxidant capacity (DPPH) is expressed as inhibition \% equivalents $\mathrm{mg} / 100 \mathrm{~g}$.

\section{Color attributes of the resultant WMBF biscuits:}

Color is one of the majority significant sensorial attributes that have a direct influence on consumer preference for any product. Particular concern must be paid to bakery products to get consumer attention. The color results were shown in $L^{*}, a^{*}$ and $b^{*}$ where the $L^{*}$ value indicates a brightness from 0 black to 100 white, $a^{*}$ expresses the degree of redness-greenness of a negative value (green hue) and at a positive value (red hue) the $b^{*}$ value measures the degree of yellowingbluing, moving from negative blue to positive yellow.
The color parameters $\left(L^{*}, a^{*}\right.$ and $\left.b^{*}\right)$ of biscuit samples were assessed and given in Table (8). The $L^{*}$ values of the resultant biscuits ranged from 61.72 to 58.41 . The WMBF biscuit (Cont.) showed the highest $L^{*}$ values. ANOVA cleared significant effect $(P \leq 0.05)$ of the role of supplementation by WOF and /or RS for $L^{*}$ values of produced biscuits. Moreover, data presented in Table (8) showed that $\mathrm{a}^{*}$ and $\mathrm{b}^{*}$ values were increased by using WOF and/or RS. The values of $a^{*}$ and $b^{*}$ were improved from 6.47 to 9.17 and from 26.94 to 33.81 , respectively.

Table (8): Color parameters of the resultant WMBF biscuit with WOF and/or R.S

\begin{tabular}{cccc}
\hline Sample & ${ }^{*} \mathbf{L}$ & ${ }^{*} \mathbf{a}$ & ${ }^{*} \mathbf{b}$ \\
\hline Cont. & $61.72^{\mathrm{a}^{* *}} \pm 0.02$ & $6.47^{\mathrm{c}} \pm 0.01$ & $26.94^{\mathrm{e}} \pm 0.01$ \\
T1 & $58.93^{\mathrm{e}} \pm 0.05$ & $6.46^{\mathrm{c}} \pm 0.00$ & $28.00^{\mathrm{c}} \pm 0.02$ \\
T2 & $60.78^{\mathrm{b}} \pm 0.02$ & $7.33^{\mathrm{a}} \pm 0.03$ & $29.02^{\mathrm{a}} \pm 0.02$ \\
T3 & $60.15^{\mathrm{c}} \pm 0.05$ & $6.90^{\mathrm{b}} \pm 0.02$ & $28.31^{\mathrm{b}} \pm 0.02$ \\
T4 & $59.64^{\mathrm{d}} \pm 0.02$ & $6.80^{\mathrm{b}} \pm 0.01$ & $27.18^{\mathrm{d}} \pm 0.00$ \\
\hline
\end{tabular}

Cont. $=100 \% \mathrm{WMBF}$ used as biscuit sample control, whereas biscuit blends were $\mathrm{T} 1=90 \% \mathrm{WMBF}: 10 \% \mathrm{RS}, \mathrm{T} 2=90 \% \mathrm{WMBF}$ : $10 \%$ WOF, T3 $=80 \%$ WMBF: $10 \%$ RS: $10 \%$ WO F and T4=70\% WMBF: $15 \%$ RS: $15 \%$ WOF.

${ }^{* *}$ Means in the same column with different letters are significantly different $(p \leq 0.05)$. Each mean value is followed by \pm SE (standard error) for triplicate.

Aforementioned data revealed that the used of WOF and/or RS. improved the color of WMBF biscuit to redness and yellowness. The observed decrease in $L^{*}$ value, whereas an observed elevate in $a^{*}$ (redness) and $b^{*}$ (yellowness) of the resultant-biscuits may be imputed to the biscuit surface color (brown pigments) is resulted of pigments Millard reaction and sugar caramelization. Our data are in accordance with those of Kim et al. (2014) revealed that the $L^{*}$ value of cookies made from incorporation of barley with oat increased with a rise barley level and $a^{*}$ and $b^{*}$ values increased with increasing level of oat. Moreover,
Laguna et al. (2011) who found that no significant effect on $a^{*}$ value among the formulas of biscuit which it was made from wheat flour partially replacing with resistant starch comparing with control.

\section{CONCLUSIONS}

The aim of this investigation was to maximize the nutritional promoting characteristics and sensory properties of whole meal barley flour biscuits by adding resistant starch (RS) and/or whole meal oat flour (WOF). The resultant biscuit was distinguished 
by good organoleptic properties such as texture and color and good nutritional value, additionally improving the active components of barley whole meal biscuit. That way, the production of this biscuit as functional biscuit with good sensorial properties is an opportunity to produce a new bakery product in market with healthy content.

\section{REFERENCES}

AOAC (2000). Official Methods of Analysis, $17^{\text {th }}$ edn. Washington, DC: Association of Official Analytical Chemists.

Aune, D., N. Keum, E. Giovannucci, L. T. Fadnes, P. Boffetta, D. C. Greenwood and T. Norat (2016). Whole grain consumption and risk of cardiovascular disease, cancer, and all cause and cause specific mortality: systematic review and dose-response meta-analysis of prospective studies. Biomed. J., 353: 1-14. https://doi:10.1136/bmj. i2716

Baik, A. and S. Ullrich (2008). A review on barley improvements, characteristics and its uses in cereal-based food products. J. Cereal Sci., 21: $115-121$

Baghurst, P. A., K. I. Baghurst and S. J. Record (1996). Dietary fiber, non-starch polysaccharides and resistant starch - a review. Food Australia, 48: 2-S35.

Baixauli, R., A. Salvador and S. M. Fiszman (2008). Textural and color changes during storage and sensory shelf life of muffins containing resistance starch. Eur. Food Res. and Technol., 226: 523-530.

Bondia-Pons, I., A. Aura, S. Vuorela, M. Kolehmainen, H. Mykka“ nen, H. and H. Poutanen (2009). Rye phenolics in nutrition and health. $\mathrm{J}$. Cereal Sci. 49 (3), 323-336. https://doi.org/10.1016/j.jcs.2009.01.007

Englyst, H. N., S. M. Kingman and J.H. Cummings (1992). Classification and measurement of nutritionally important starch fractions. Eur. J. Clin. Nutr., 46: 33-50.

Drakos, A., L. Andrioti-Petropoulou, V. Evageliou and I. Mandala (2019). Physical and textural properties of biscuits containing jet milled rye and barley flour. J. Food Sci. Technol., 56(1): 367- 375. https://doi: 10.1007/s13197018-3497-z.

Gupta, M., A. S. Bawa and N. Abu-Ghannam (2011). Effect of barley flour and freeze-thaw cycles on textural nutritional and functional properties of cookies. Food Bioprod. Process., 89(4): 520-527. https://doi.org/10.1016/j.fbp.2010.07.005

Hendek, M.E., M. Bektaş and R. Atasoy (2020). Effect of cereals milling on the contents of phytic acid and digestibility of minerals and protein. Ukra Food J., 9(1): 136- 147

Hoda, M. Z., Elshawaf, A. M., A. Makhzangy and M. S. Hussein (2018). Chemical, rheological and sensory properties of Wheat- Oat flour composite cakes and biscuits. J. Product and
Devel., 23: 287- 306. https://doi: 10.21608/jpd.2018.42018

Holtekjølen, A. K., A. B. Baevre, M. Rodbotten, H. Berg and S. H. Knutsen (2008). Antioxidant properties and sensory profiles of bread containing barley flour. Food Chem., 110:414421. https://doi.org/10.1016/j.foodchem.2008.02.054

Kim, B. Y., H. S. Choi and E. S. Lyu (2014). Quality characteristics of cookies prepared with oat and barley powder. Korean J. Food Cook Sci., 30 : 428-434. https://doi.org/10.9724/kfcs.2014.30.4.428

Laguna, L., A. Salvador, T. Sanz and M. F. Susana (2011). Performance of a resistant starch rich ingredient in the baking and eating quality of short- dough biscuits. LWT., 44:737- 746. https://doi.org/10.1016/j.lwt.2010.05.034.

Lebesi, D. M. and C. Tzia (2011). Effect of the addition of different dietary fiber and edible cereal bran sources on the baking and sensory characteristics of cupcakes. Food Bioprocess Technol., 4: 710-722. https:// doi 10.1007/s11947-009-0181-3

Lesschaeve, I. and A. C. Noble (2005). Polyphenols: factors influencing their sensory properties and their effects on food and beverage preferences. Am. J. Clin. Nutr., 81(1): 330S335S. https://doi.org/10.1093/ajcn/81.1.330S

Lineback, D. R. (1997). Resistant starch. AACC short course on starch: structure, properties, and food use. Chicago, IL, 1997.

Makpoul, K. R. and A. A. Ibrahem (2015). Improving Biscuits nutritional value using quinoa flour, J. Food and Dairy Sci., 6 (12):771- 780.

McDonald, S., P. D. Prenzler, M. Antolovich and K. Robards (2001). Phenolic content and antioxidant activity of olive extract. Food Chem., 73: 73-84. https://doi.org/10.1016/S03088146(00)00288-0

Meullenet, J. F. C., J. Gross, B.P. Marks and M. Daniels (1998). Sensory profiling of cooked rice and its correlation to instrumental parameters using an extrusion cell. Cereal Chem., 75:714-720.

Miranda M., A. Vega-Gálvez, J. Vergara, E. Uribe, L. Puente and E.A. Martínez (2010). Nutrition facts and functional potential of quinoa (Chenopodium quinoa Willd.). An ancient Andean grain: A review. J. Sci. Food Agri., 90 (15): 2541-2547.

Newman, R.K., K. C. Ore and J. Abbott (1998). Fiber enrichment of baked products with a barley milling fraction. Cereal Foods World, 43(1):23- 25. http://agris.fao.org/agris search/search.do?recordID $=$ US1997054705

Ott, L. (1988). An introduction to statistical methods and data analysis. $3^{\text {rd }}$ ed. PWS-Kent, Boston, M.A.

Ovando-Martinez, M., Whitney, B. L. Reuhs, A. C. Doehlert and S. Simsek (2013). Effect of hydrothermal treatment on physicochemical and digestibility properties of oat 
starch. Food Res. Int., 52: 17-25. https://doi.org/10.1016/j.foodres.2013.02.035

Pareyt, B., E. Wilderjans, H. Goesaert, K. Brijs and J.A. Delcour (2008). The role of gluten in a sugar- snap cookie system: a model approach based on gluten- starch blends. J. Cereal Sci.,48: 863- 869. https:// doi.org/10.1016/j.jcs.2008.06.011

Piga, A., P. Catzeddu, S. Farris, T. Roggio, A. Sanguinetti and E. Scano (2005). Texture evaluation of Amaretti cookies during storage. Eur. Food Res. Tech., 221: 387-391. https://doi 10.1007/s00217-005-1185-5

Poutanen, K., N. Sozer and G. D. Valle (2014). How can technology help to deliver more of grain in cereal foods for a healthy diet? J. Cereal Sci., 59: 327-336. https://doi: 10.1016/j.jcs.2014.01.009 e.

Rasane, P., A. Jha, L. Sabikhi, A. Kumar and V. S. Unnikrishnan (2015). Nutritional advantages of oats and opportunities for its processing as value added foods - a review. J. Food Sci. Technol., 52:662-675. https://doi: 10.1007/s13197-013-1072-1.

Sharma, P. and H. S. Gujral (2010). Antioxidant and polyphenols oxidase activity of germinated barley and its milling fractions. Food Chem., 120 : 673-678. https://doi.org/10.1016/j.foodchem.2009.10.059

Sharma, P., H. S. Gujral and B. Singh (2012). Antioxidant activity of barley as affected by extrusion cooking. Food Chem., 131: 1406-1413. https://doi.org/10.1016/j.foodchem.2011.10.009

Sharma, P. and H. S. Gujral (2014). Cookies making behavior of wheat- barley flour blends and effects on antioxidant properties. LWT, 55: 301307. https://doi.org/10.1016/j.lwt.2013.08.019

Shalini, H. and J. Sudesh (2005). Organoleptic and nutritional evaluation of wheat biscuits supplemented with untreated and treated fenugreek flour. Food Chemistry, 90: 427 435.

Soares, R. M. D., A. DeFrancisco, P. Rayas-Duarte and V. Soldi (2007). Brazilian hull-less and malting barley genotypes: I. Chemical composition and partial characterization. J. Food Qual., 30: 357-371. https://doi.org/10.1111/j.1745-4557.2007.00127.x

Stone, H. and J. L. Sidel (2004). Sensory evaluation practices. San Diego, CA: Elsevier Academic Press. $3^{\text {rd }}$ ed. 377 p.

Sudha, M., R. Vetrimani and K. Leelavathi (2007). Influence of fiber from different cereals on the rheological characteristics of wheat flour dough and on biscuits quality. Food Chem., 100, 1365-1370.

Vasan, A., P. Boora and N. Khetar paul (2017). Grab a health bite: Nutritional evaluation of barleybased cookies. Asian J. Dairy\& Food Res, 36(1): 76-79.

Verma, A. K. and R. Banerjee (2010). Dietary fiber as functional ingredient in meat products: a novel approach for health living- a review. J. Food Sci. Technol., 47: 247- 257.

Vitali, D., I. V. Dragojevic and B. Sebecic (2009). Effects of incorporation of integral raw materials and dietary fiber on the selected nutritional and functional properties biscuits. Food Chem., 114: $1462-$

1469. https://doi.org/10.1016/j.foodchem.2008.11.032

Wang, T., S. H. Soyama and Y. Luo (2016). Development of a novel functional drink from all-natural ingredients using nanotechnology. LWT, 73:458-466. https://doi: 10.1016/j.lwt.2016.06.050.

White, P. and M. Broadley (2007). Genetic aspects of mineral bio fortification. Comp. Biochem. Physic. -Part A. 4 (146): S246.

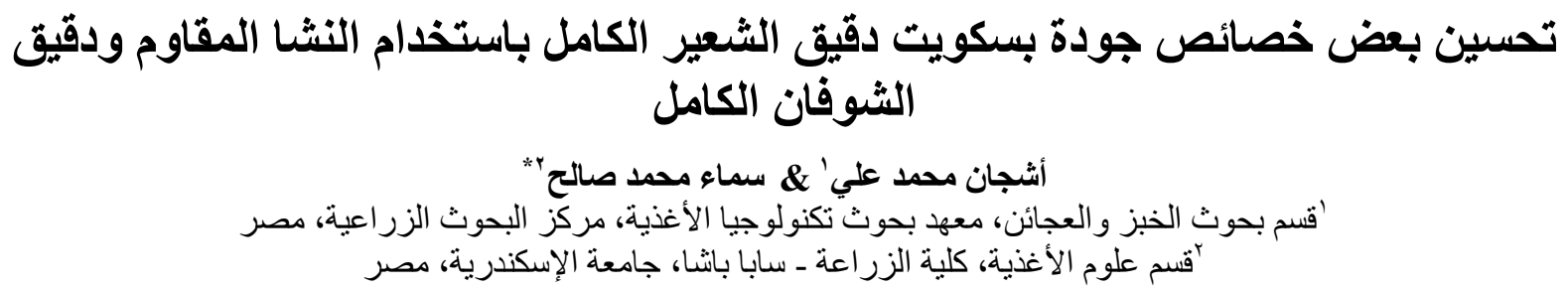

تمت دراسة تأثير استخدام النشا المقاوم (RS) ودقيق الثوفان الكامل (WOF) لتحسين الخصائص الحسية والوظيفية لبسكويت

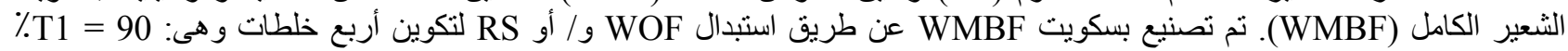
WMBF: \%T4 = 70 gOF \%RS: 10 \%WMBF: 10 \%T3 = 80 ،WOF \%WMBF: 10 \%T2 = 90 ،RS \%WMBF: 10 لعمل عينة بسكويت كنترول. تم تقييم البسكويت من حيث خصائص استخدم دقيق التصنيع و التركيب

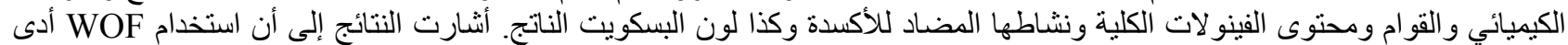

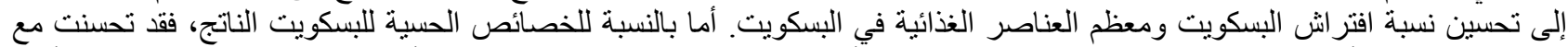

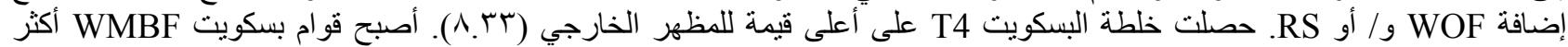

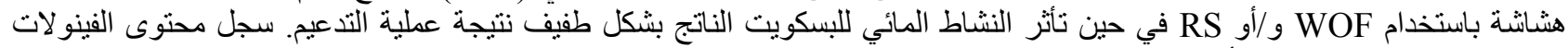

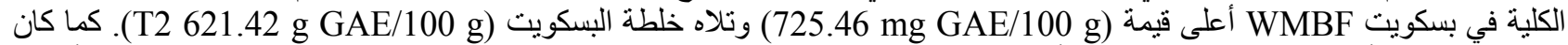

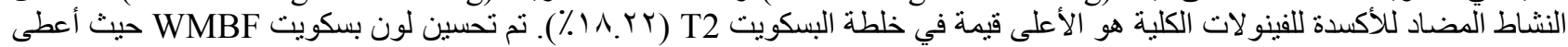

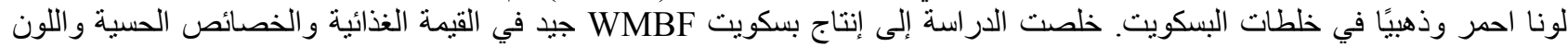
و المذاق و القبول العام. 